\title{
9. Marketing Organization, Innovation and Agricultural Cooperatives
}

\author{
Matthew T.G. Meulenberg'
}

\section{Summary}

This paper is concerned with the innovation in marketing organization in agricultural cooperatives. A framework for the analysis of marketing organization is proposed and the interaction hetween functions, institutions and relationships is emphasized. Current marketing literature has been used to identify the marketing philosophy of a company, the capacities of management, coordination mechanisms, and the method of investing in market strategies. Concepts and ideas concerning innovation in organizations which appear relevant to marketing organization are reviewed and the narket strategies to be chosen in view of given particular market developments are introduced and their impact on cooperative marketing organization analyzed. Subsequently the evolution of cooperative marketing organization is summarized in three models. This evolution seems to reflect the way in which Western European cooperatives actually develop.

\section{Introduction}

Innovation as a subject of marketing theory has been analyzed with particular emphasis on new products and services. Although an appropriate marketing organization is crucial for successful marketing, there has been no extensive investigation of innovation in marketing organization. A special organizational characteristic of marketing agricultural products and food is that the marketing often embraces the entire agricultural production and food chain from the farmer to the final consumer.

This paper is concemed with the innovation in marketing organization in agriculture. It pays particular attention to the innovation of marketing organization in agricultural cooperatives. The organization of marketing in a cooperative enterprise is very specific because of the relationship between the farmers and their cooperative company. Although this paper has been written at the conceptual level, it hopefully provides a realistic picture of the actual trends emerging within the marketing organization of European cooperatives.

${ }^{1}$ Department of Marketing and Marketing Research, Agricultura) University Wageningen, The Netherlands. 
Our paper is organized as follows. First, some general characteristics of marketing organization are presented and factors influencing the innovation in marketing organization are reviewed. The important changes that have taken place in Western European agricultural markets and the market strategies that have emerged as a result are also discussed. Subsequently the innovation in marketing organization in agricultural cooperatives is analyzed and we conclude our analysis by presenting three cooperative models, which describe the evolution of cooperative marketing organization.

\section{General characteristics of marketing organization}

\section{I A framework of marketing organization}

Marketing processes, which, according to Kotler (1991), consist of Analysis, Planning, Implementation and Control, are organized by marketing decision makers. Marketing tasks and responsibilities have to be determined and assigned to specific business units, departments and persons. Marketing organization does not only concern specific marketing tasks but also the relationship between marketing and the various departments of a company. Shapiro (1977) lists eight problem areas of "necessary cooperation but potential conflict" between marketing and production: "(i) capacity planning and long range sales forecasting, (ii) production scheduling and short range sales forecasting, (iii) delivery and physical distribution, (iv) quality assurance, (v) breadth of product line, (vi) cost control, (vii) new product introduction and (viii) adjunct services ...".

In order to understand the dynamics of the marketing organization associated with a product the following framework may be useful:

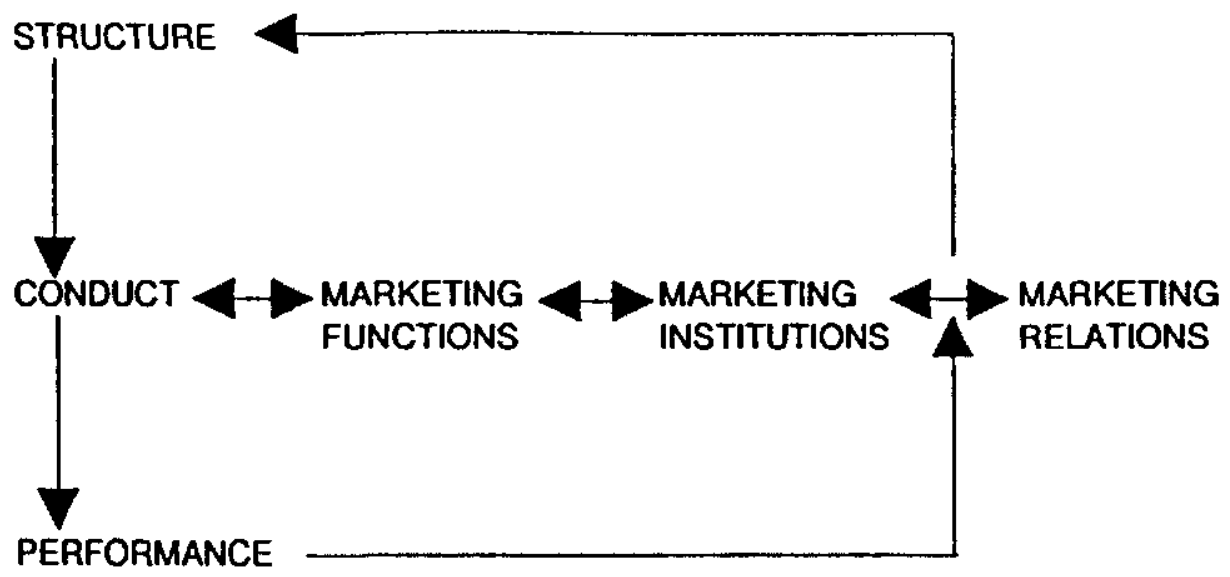


Marketing functions are fulfilled by the producers themselves or by specialised marketing companies. The institutions performing marketing functions, develop special relationships with their clients and suppliers. Wind and Lilien (1993) note that one of the important changes in market strategies in the twenty-first century will be a shift from traditional marketing institutions towards innovative marketing institutions. A marketing operation consisting of functions, institutions and relationships brings about specific market conduct.

According to the well-known Structure Conduct Performance paradigm, market conduct is determined by market structure and influences the performance of a company in terms of profit or market share. Our framework suggests that performance, measured in terms of profit, influences marketing institutions, in relation to their size and their marketing capacities.

Market structure influences the way a company markets its products. Where there is perfect competition, for example, a company is less in control of the marketing mix than where there is oligopoly with product differentiation. In the case of perfect competition, therefore, marketing institutions such as cooperatives or marketing boards, are often set up in order to market the generic product of a group of firms.

The interdependence between marketing functions and marketing institutions should be taken into account when markets are in the process of change. In fact, marketing institutions may not be able to cope with specific market challenges: marketing of branded products, for example, will not be feasible if a product is sold through an auction.

\subsection{Some features of marketing organization}

Marketing organization in a company involves marketing philosophy, organizational structure, and the system of marketing.

Basically, the marketing philosophy of a company may range between "Make the Product and Sell it" on the one hand, and "Choose the Value, Provide the Value and Communicate the Value" on the other hand (Kotler, 1991). The impact of a company's marketing philosophy on actual marketing depends to a large extent on how committed top management are to that philosophy.

Jaworski and Kohli (1993) characterize the organizational structure and system of marketing by the structural variables formalization, centralization and departmentalization. These variables have to be considered by agribusiness companies when organizing marketing operations. In cooperatives, the structural variables formalization, centralization and departmentalization of marketing organization do not only refer to marketing organization within the cooperative company but also to marketing organization which affects the relationship between the cooperative company and the members of the cooperative. As a result, a variety of coordinative mechanisms may have to be used including mutual adjustment, direct supervision, standardization of work procedures, 
standardization of output, standardization of skills and/or the standardization of norms (Mintzberg, 1989). Concepts drawn from marketing literature such as administered, contractual or corporate vertical marketing systems are also relevant (Stern and El Ansary, 1992).

Heide (1994) distinguishes the following approaches to inter-organizational governance in marketing channels:

- the marketing literature: the institutional and functional marketing school using economic efficiency as the criterion for organizing the marketing channel (e.g. Bucklin, 1970), the behaviourial dynamics marketing school, using the ability to control the role performance of other channel members as a criterion and, as a result, focusing on sources of power and the exercise of power (Stern, 1969; Hunt, S.D. and J.R. Nevin, 1974) and scholars analyzing the joint influence of cost and control considerations on channel structure (Jeuland and Shugan, 1983; McGuire and Staelin, 1983; Moorthy, 1988);

- resource dependence theory which: "..views interfirm governance as a strategic response to conditions of uncertainty and dependence" (Pfeffer and Salancik, 1978);

- "transaction cost theory views governance in terms of designing particular mechanisms for supporting economic transactions;

- relational contracting theory developing a distinction between discrete exchange which is nothing more than the transfer of ownership to a product or service and relational exchange, accounting explicitly for the historical and social context in which transactions take place" (Dwyer, et al, 1987).

An important characteristic of organizing marketing activities in a marketing channel is the presence of a channel leader. Important questions in this respect are: who is the channel leader and what power bases does he have at his disposal?

\subsection{Factors influencing the innovation in marketing organization}

The innovation in marketing organization can be generated by exogenous factors, for example, market driven, by endogenous factors, for example, as a result of company research, or by a combination of both.

An important exogenous factor leading to innovation in marketing organization is the changing agricultural and food market in which agribusiness companies are now operating. Changing agricultural and food markets have stimulated the shift towards marketing management. On the basis of customer orientation, a marketing policy is developed which uses the marketing instruments available in a coherent way. This development in agricultural marketing policies brings about changes in the performance of marketing functions both in the institutional organization of marketing and in the relations between institutions. 
Technological developments also create new marketing opportunities for agribusiness companies. New discoveries in science and technology offer opportunities for the development of new products or for lowering the cost of production whilst innovations in transport and storage technology increase the opportunity for using logistics as a marketing tool. The evolution of communication technology has had a tremendous impact on marketing communication and information transfer, Electronic Data Interchange being a case in point.

Marketing organization is also changing because of forces endogenous to companies, such as internal Research and Development programs, changing managerial capacities and attitudes and developments in planning procedures.

Various notions and theories about innovation and organization in general also appear relevant to the innovation in marketing organization. The argument of Schumpeter (see for instance Kamien and Schwartz, 1982) that some monopoly power in a company is favourable to innovation is well known. Monopolistic profits create financial resources which can be invested in innovative market strategies. Moreover, monopolistic market power makes the market introduction of new products easier. Given such observations it has been argued that large companies are often better equipped for marketing innovation. Futia (1980) was one of those who developed a model which "..is consistent with the claim that innovative activity increases with industry concentration but less so in industries with extensive opportunities for innovation than in those with few opportunities" (Kamien and Schwartz, 1982). This argument seems relevant to agribusiness and food industry, where fundamental new innovations are scarce.

March and Simon (1993) argue that "the availability of slack money and personnel not committed to on-going programs enhances the commitment in a company to new programs and program elaboration". They emphasize also the importance of individuals or units having planning responsibilities without heavy operating responsibilities. According to these scholars the creation of a new unit is the only way to secure an innovation that is not excessively bound and hampered by tradition and precedent. They suggest that innovation will be most rapid and vigorous if "stress" on the organization is neither too high nor too low (March and Simon, 1993).

Anticipated market results will also have an impact on the development and marketing of product innovations. Von Hippel argues that: "innovating firms will be found among those whose analyses lead them to expect a rent they consider attractive" (Von Hippel, 1988). March and Simon (1993) emphasize satisfaction as a criterion for innovation. These criteria of market results and satisfaction seem particularly relevant to the question of which company in the agricultural marketing chain will push the adoption of an innovation and will organize its marketing through the channel. 
More recently the innovation in marketing by organizing alliances has been receiving increasing attention. Bucklin (1993) is amongst those who have identified co-marketing alliances which are lateral relationships betwcen firms at the same level in the value added chain and represent a form of "symbiotic" marketing: "Only by the linking of multiple firms' resources can new systems be developed with sufficient breadth and sophistication to persuade end users to abandon current investments and upgrade to new technology".

\section{Changes in the marketing environment of agricultural cooperatives}

Since innovation in marketing and of marketing organization in agriculture is to a large extent market driven, we will make a concise review of the main trends in agricultural and food markets.

Consumer behaviour is changing significantly. Important factors underlying these changes are sluggish population growth, a greying population, smaller family units and increasingly multiracial societies. Per capita disposable income is increasing modestly, consumers are better educated and better informed about the health and environmental aspects of food and agricultural products. Food consumption is becoming more homogeneous as a result of general trends, such as the internationalization of food production and trade and the internationalizing of purchasing and consumption habits. However, individualism and diversity in consumer behaviour are also on the increase motivated by the need for self actualization and self fulfilment (Maslow, 1954) and because of a greater diversity in values and norms (see for example Popcorn, 1991).

Competition is increasing because of the internationalization of agricultural and food trade. An increasing number of exporting countries, including those in Eastern European and several developing countries are putting more pressure on international export markets, particularly those in Western Europe. These countries often have a competitive edge because of the low cost of labour and energy, but they are often weak in infrastructure, knowledge and craftsmanship. Further the abolition of trade barriers by GATT has stimulated competition.

Governments have reduced the amount of direct support to agriculture, especially price and income support, because of budgetary problems. They put more side constraints on agricultural production and marketing because of environmental problems.

Perhaps the most important marketer in the food chain is retail business. In many European countries food retailing is dominated by a small number of big retailers often operating on an international scale. These retail chains develop their own marketing policies, they are cost conscious and have strong purchasing power at their disposal sometimes reinforced by international alliances.

There are a great many developments on the input side of agriculture and food industry which stimulate innovation in agricultural marketing. These 
include new breeding results and new methods of planning and decision making. All offer opportunities for innovation in production, logistical operations and quality control.

\section{Strategies of agricultural cooperatives in response to market developments}

Given the market developments reviewed here, cooperatives must select their strategy from amongst those well-known (Porter, 1980) market strategies: Overall Cost Leadership, Focus/Segmentation and Differentiate.

Overall Cost Leadership implies price competition on the basis of efficiency in production and logistics. This strategy can be successful in scrving priceconscious consumers. It may also be helpful for cooperatives concentrating on marketing raw materials and semi-finished products, while leaving production and marketing of consumer goods to other companies. A policy of such overall cost leadership may be attractive if there is a shortage of a particular agricultural product. However, where there is abundant agricultural supply and overcapacity in agribusiness companies, a low-cost oriented cooperative is in a weak bargaining position and is not able to transform efficiency improvements into profits for its farmers.

Focus/Segmentation is an important competitive strategy for cooperatives because many agricultural and food products are in the maturity stage or the saturation stage of the product life cycle. At this stage consumers are familiar with the product and have developed specific wants and needs with respect to that product. By serving the specific wants and needs of a particular market segment, cooperatives may establish consumer loyalty. A strategy of focus/segmentation requires that cooperatives add value to the agricultural product, which will be in particular appreciated by a specific market segment. Innovative research and development and production and marketing are necessary for an effective strategy of focus/segmentation. A cooperative may also be encouraged to choose a strategy of focus/segmentation because focusing on a specific product-market combination will increase its competitive potential.

In today's very competitive food market it is an attractive proposition for cooperatives to differentiate their products from competitive supply. Such products should be recognizable in the market place. Constant and high quality is an important instrument in this respect. Uniform and effective packaging is important too. A strong brand image is the most effective type of product differentiation. The strength of a brand image is not only built upon the instrumental values of a product but also on the expressive and emotional values of the brand. Quality labels and environmental labels also differentiate product quality in the market. 
In our opinion, agricultural cooperatives have to search for the added value components of their products and therefore they should go for Focus/ Segmentation and/or Differentiation strategy. In Western European agriculture, a strategy of Overall Cost Leadership does not seem attractive because consumers are more interested in better quality, variety and service than in consuming larger quantities; Western European agriculture faces comparatively high labour and energy costs, and overproduction and overcapacity in agricultural production make it difficult to build a strong market position on the basis of low prices alone.

A selection made from these basic market strategies should be augmented by a number of supportive strategies. Market leadership and chain management would appear to be relevant strategies here.

Market leadership is attractive because portfolio analyses (Kerin et al., 1990) and PIMS (Buzzell and Gale, 1987) show a positive relationship between return on investment and market share. Accumulation of experience, both in the economies of scale in production and in marketing and distribution have been discussed extensively as a possible reason for this positive relationship (see for example: Kerin, et al, 1990).

Chain management by coordination of processes and quality control through the marketing channel, for example, will support the effectiveness of basic market strategies such as focus/segmentation and product differentiation. This is in particularly important for fresh produce such as fruit and vegetables and fresh meat.

\section{Innovating the marketing organization of agricultural cooperatives}

It has been argued that agricultural cooperatives should adopt focus/ segmentation and/or differentiation as preferred basic market strategies. Switching from selling towards a well-defined market strategy requires the innovation of the marketing organization and this means:

- changing the marketing philosophy from selling products to market orientation;

- improving marketing expertise and marketing coordination;

- creating more room for investments in market strategies.

\subsection{Innovating the marketing philosophy from selling towards market orientation}

Before the nineteen fifties, Western European agricultural cooperatives concentrated their marketing efforts on selling the products of cooperative members at the highest price. They operated locally or regionally and served predominantly domestic markets. The dynamics of current markets has forced 
cooperatives to adapt marketing policies to customers' needs and to search for competitive advantage. A well-defined mission should serve as a frame of reference for a market-oriented cooperative strategy.

Organizing the agricultural cooperative towards a market-oriented strategy is in the first instance the task of the cooperative company. The cooperative company operates closer to the market than the farmer-members themselves and is more aware of the added value that can be generated by market orientation than its members. This is in line with the argument we have already quoted from Von Hippel, "... innovating firms will be found among those whose analyses lead them to expect a rent they consider attractive" (Von Hippel, 1988).

Market orientation of a company implies that innovation has become a permanent characteristic of its market strategy. Following the argument of March and Simon (1993) "... innovation will be most rapid and vigorous when the "stress" on the organization is neither too high nor too low", there must be a harmony between innovative aspirations and the results both within the cooperative company and between the cooperative company and the farmer members. Therefore, the cooperative company has to "market" innovative policies to its members, because they are the ultimate beneficiaries of its policies.

Innovative market strategies, like segmentation and differentiation, can be frustrated by existing organizational structures and by a traditional cooperative marketing policy orientated to only selling the product. This problem may be avoided by the creation of separate business units (March and Simon, 1993). In fact, many cooperatives have set up business units which serve specific market segments, use specific technologies and have own profit responsibilities. If consumers needs can only be satisfied by specific processing methods and services and specific agricultural products, the cooperative will have to segment its farmer-members too.

Co-marketing alliances (Bucklin, et al., 1993) might also be a useful device for a cooperative to establish, in cooperation with other companies or organizations that have an innovative marketing philosophy. Up to now this type of alliance does not seem particularly popular with agricultural cooperatives.

\subsection{Innovation in marketing coordination and marketing authority in agricultural cooperatives}

It has been argued that in market-oriented cooperatives, the cooperative company should take the lead in innovating market strategies. Consequently, cooperative management must have sufficient authority to develop and implement market strategies. Such authority will be based in the first instance on the quality of managers. In order to attract competent managers, a cooperative will have to offer adequate salaries and give managers sufficient room for alert and creative decision making. The first condition can only be fülfilled by 
companies, who are able to carry the cost of employing qualified managers. The second condition requires that managers have sufficient room for decision making, which is either guaranteed by a covenant between the cooperative board and the management of the cooperative company or by transforming the cooperative company into a limited company whose shares are in the hands of the cooperative union.

A cooperative company does not only develop innovative strategies but also has to implement them. Consequently, there must be room for adequate coordination of policies and operations between cooperative company and farmer members. The cooperative structure must allow for the use of effective coordination mechanisms.

\subsection{Innovating opportunities for investment in cooperative market strategies}

Individual farmers do not have the means at their disposal for carrying out innovative rescarch and development and for the introduction of new products. Many of them have overcome this problem by joining a cooperative. The present shift towards market orientation means continuous investment in the innovation of market strategies. Higher marketing costs stimulate the creation of bigger cooperatives, able to profit from economies of scale and scope in marketing.

In a cooperative farmer members have to make decisions about important investments in market strategies developed by the cooperative company. The farmers attitude towards such types of investment is very much affected by the level of their commitment and involvement in their cooperative. Methods of financing cooperatives which personalize the farmers' contribution to cooperative assets might also encourage the farmers' willingness to invest in cooperative market strategies. Transforming the cooperative company into a limited company the majority of whose shares are owned by the cooperative, might make the acquisition of capital from third parties easier.

\section{Conclusion}

By changing the marketing philosophy, by stricter coordination of marketing operations and by making more investments in market strategy, agricultural cooperatives are changing from local, production-driven companies to intemational, market-driven companies. The resulting evolution in organizational structure is summarized in the following models (N.C.R., 1993). It should be stressed that these structures are discussed from the marketing point of view and this is clearly only a partial analysis. 


\section{References}

Bucklin L.P., Sengupta S., 1993, "Organizing Successful Co-Marketing Alliances", Journal of Marketing, 57, April, pp. 32-46.

Bucklin L.P. (ed.), 1970, Vertical Marketing Systems, Scott, Foresman and Company, Glenview, III.

Buzzell D.L., Gale B.T., 1987, The PIMS Principles, The Free Press, New York. Dwyer R.O., Schurr P.H., Oh S., 1987, "Developing Buyer-Seller Relationships", Journal of Marketing, 52, April, pp. 21-34.

Futia C.A., 1980. "Schumpeterian Competition", Quarterly Journal of Economics, 94, pp. 675-695.

Heide J.B., 1994, "Interorganizational Govemance in Marketing Channels", Journal of Marketing. 58, January, pp. 71-85.

Hunt S.D., Nevin J.R., 1974, "Power in a Channel of Distribution: Sources and Conscquences", Journal of Marketing Research, XI, May, pp. 186-193.

Jaworski B.J., Kohli A.K., 1993, "Market Orientation: Antecedents and Consequences", Journal of Marketing, 57, July, pp. 53-70.

Jeuland A., Shugan S.M., 1983, "Managing Channel Profits", Marketing Science, 2, Summer, pp. 239-272.

Kamien M.I., Schwartz N.L., 1982, Marketing structure and innovation, Cambridge University Press, Cambridge.

Kerin R.A., Mahajan V., Varadarajan P.R., 1990, Contemporary Perspectives on Strategic Market Planning, Allyn and Bacon, Boston.

Kotler P., 1991, Marketing Management, Analysis, Planning, Implementation and Control, 7th ed., Prentice Hall Inc., Englewood Cliffs.

March J.G., Simon H.A., 1993, Organizations, 2nd ed. Blackwell Publishers, Cambridge, Massachusetts.

Maslow A.H., 1954, Motivation and Personality, Harper and Row, New York.

McGuire T.W., Staelin R., 1983, "An industry Equilibrium Analysis of Downstream Vertical Integration", Marketing Science, Spring, pp. 161-191. Mintzberg H., 1989, Mintzberg on Management, The Free Press, New York. Moorthy K.S., 1988, "Strategic Decentralization in Channels", Marketing Science, 7, Fall, pp. 335-355.

N.C.R., 1993, Marketing en Coöperatie, Nationale Coöperatieve Raad voor land- en tuinbouw, Rijswijk, Eburon, Delft.

Pfeffer J., Salancik R., 1978, The External Control of Organizations: A Resource Dependence Perspective, Harper and Row, New York.

Popcom F.B., 1991, The Popcorn Report, Doubleday, New York.

Porter M.E., 1980, Competitive Strategy: Techniques for Analyzing Industries and Competitors, Free Press, New York.

Shapiro B.P., 1977, "Can marketing and manufacturing coexist?", Harvard Business Review, 55, pp. 104-114. 
Stern L.W., 1969, Distribution Channels: Behavioral Dimensions, Houghton Mifflin Company, Boston.

Stern L.W., El Ansary A.I., 1992, Marketing Channels, 4th ed., Prentice Hall International, Inc..

Von Hippel E., 1988, The Sources of Innovation, Oxford University Press, New York, Oxford.

Wind Y., Lilien G.L., 1993, "Marketing Strategy Models", in Eliashberg, J. and Lilien G.L. (ed.), Marketing, Handbooks in Operations Research and Management Science, Volume 5, North Holland, Amsterdam, pp. 773-826. 


\section{Appendix}

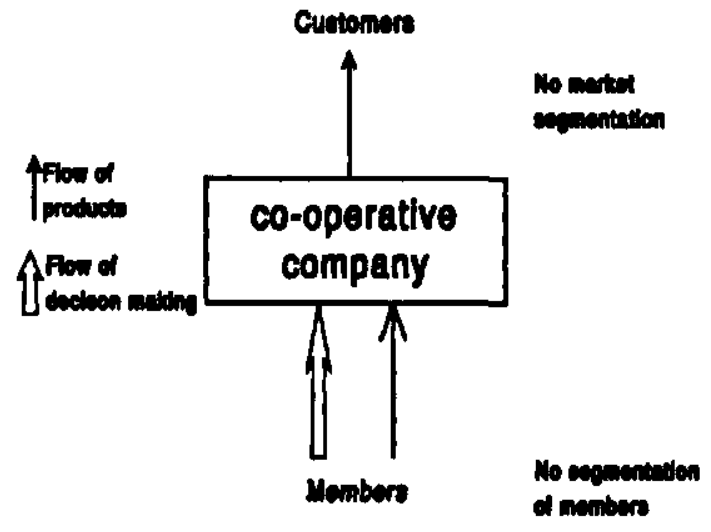

Figure 1. The basic cooperative

The basic cooperative. Members deliver products to the cooperative company, which is in charge of processing and marketing. The marketing philosophy is to sell farmers' products at the highest price. Customer-oriented marketing is limited. Members have the right and sometimes the duty to deliver their products to the cooperative company which has little marketing authority and uses coordinative mechanisms vis à vis farmer-members only to a limited extent. All farmers receive the same price for the product with some price differentiation in respect of product quality. The cooperative invests in the market only to a limited extent.

It has been argued that this structure is not attractive to Western European markets because of agricultural overproduction and demanding consumers. This structure might be viable, however, if the cooperative company was to produce for the private brand of a large retail company or if the company was to sell raw material or semi-manufactured products to a private company. 


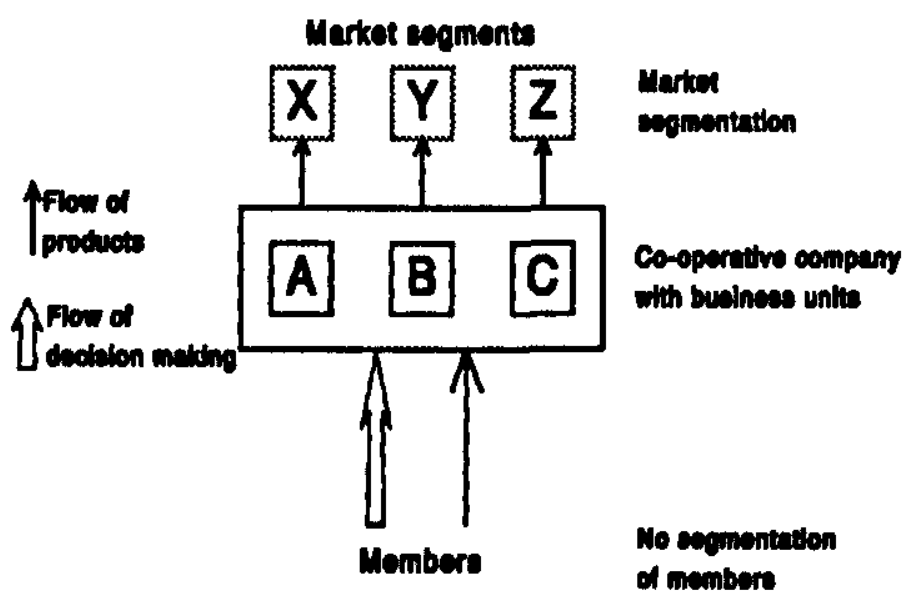

Figure 2. A cooperative with Strategic Business Units

A cooperative with Strategic Business Units. This structure allows for a market orientated marketing philosophy since processing and marketing are differentiated in Strategic Business Units. Since farmer-members have the right and the duty to deliver their products to the cooperative company, the cooperative can only coordinate the product supply of farmer members to a limited extent. Farmers receive the same price for the product with some price differentiation in respect of quality differences. The cooperative will invest in the market in order to acquire or maintain a strong position in targeted market segments.

This structure facilitates customer-oriented market strategies. However, if specific agricultural supply, in qualitative and quantitative terms, is needed by the cooperative company, this structure has its deficiencies. 


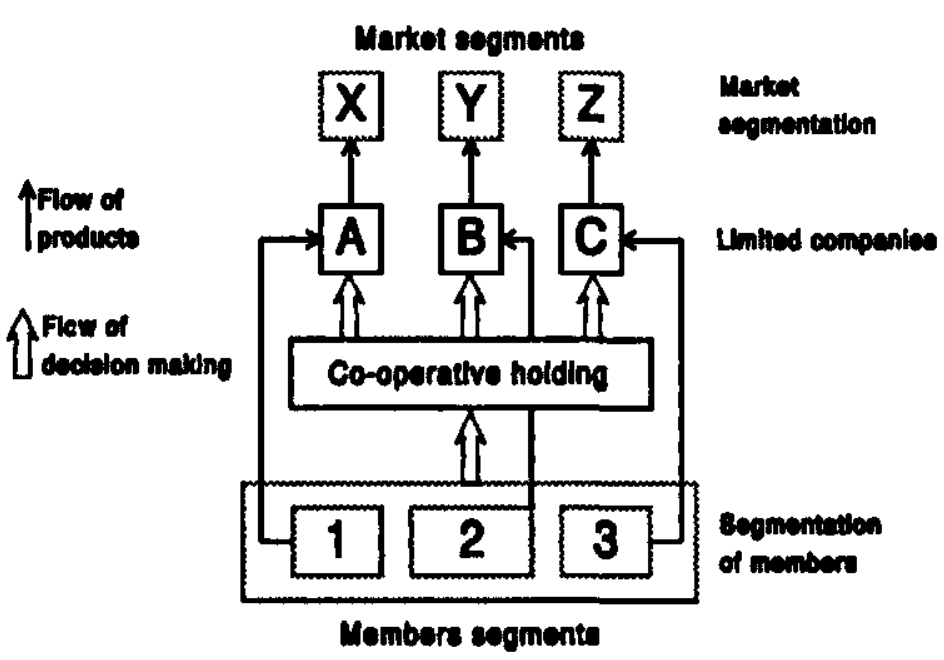

Figure 3. A cooperative holding company

A cooperative holding company. This structure allows for a customer orientated, marketing philosophy, because of the differentiation of cooperative activities in limited companies. These companies have substantial marketing authority vis à vis farmers and can coordinate agricultural inputs with their market strategy. The cooperative will invest in the market in order to acquire or maintain a strong position in targeted market segments. Financial participation of third parties in the cooperative is, in principle, feasible. The draw-back to this structure is that farmers might become alienated from their cooperative where the farmers' relationship to the cooperative company is weak. 